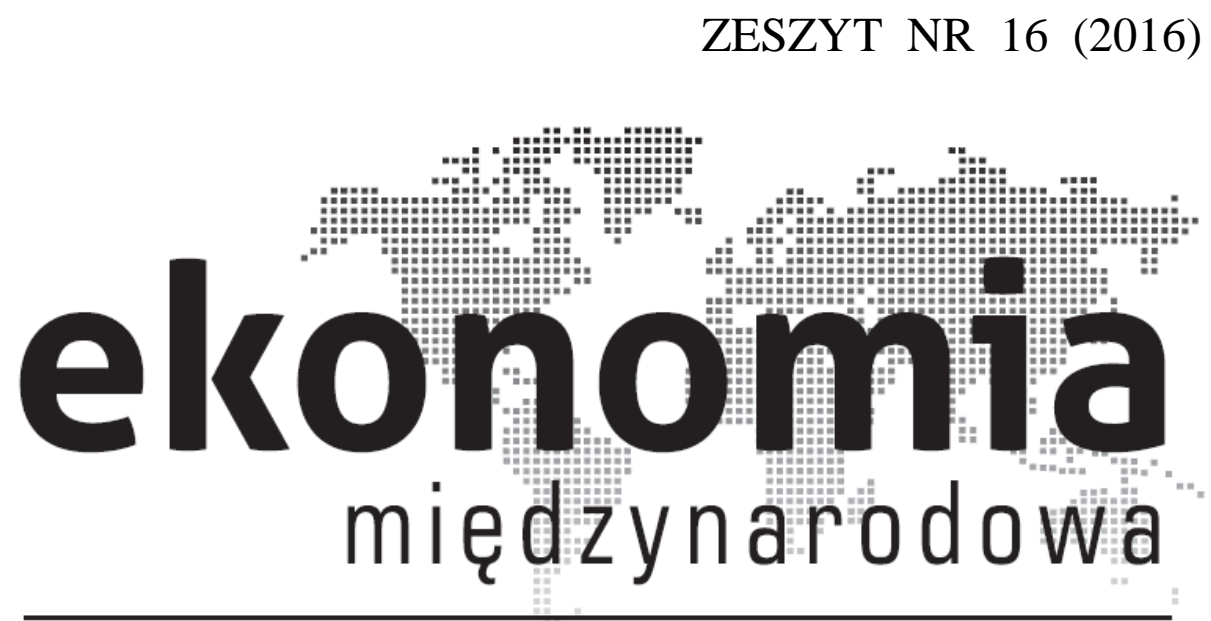

Ekonomia Międzynarodowa

Nr 16 (2016)

www.ekonomia-m.pl

ISSN: 2082-4440

EISSN: 2300-6005

Wydawca: Uniwersytet Łódzki

Wersja elektroniczna czasopisma jest wersją referencyjną
Publisher: University of Lodz

Electronic edition is the reference version of the journal
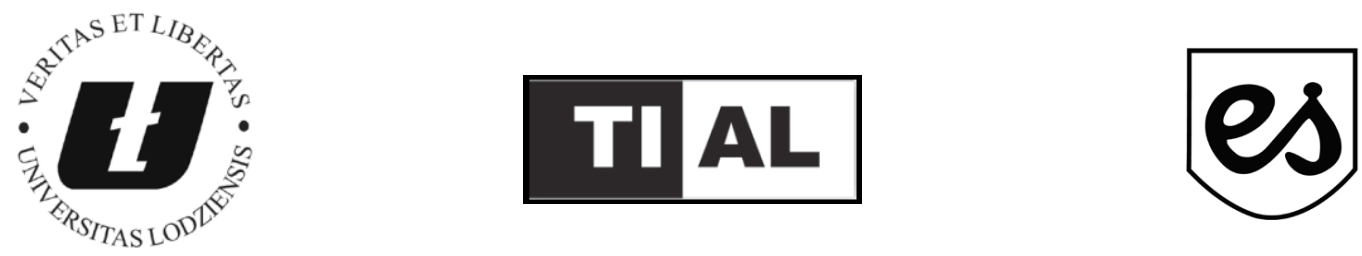


\section{Instytucjonalne uwarunkowania wspólnej polityki pieniężnej w Unii Gospodarczej i Walutowej}

Michał Laskowski*

\section{Wstęp}

Celem artykułu jest przeanalizowanie uwarunkowań instytucjonalnych polityki pieniężnej Europejskiego Banku Centralnego przy użyciu aparatu analitycznego zaproponowanego przez Douglasa Northa.

Celem badawczym pracy jest weryfikacja założenia, że w wyniku przemian gospodarczych wywołanych kryzysem finansowym 2008 r. oraz spowodowanym nim kryzysem gospodarczym nastąpiła zmiana wartości polityki pieniężnej Europejskiego Banku Centralnego.

Praca składa się z czterech części. W pierwszej zaprezentowane zostały poglądy D. Northa na instytucjonalne uwarunkowania funkcjonowania gospodarek. W części drugiej przeanalizowano formalne oraz nieformalne instytucje determinujące sposoby i warunki planowania oraz realizacji wspólnej polityki pieniężnej Unii Gospodarczej i Walutowej. W części trzeciej przedstawiono zmiany w polityce monetarnej Europejskiego Banku Centralnego będące efektem kryzysu finansowego w 2008 r. i wywołanego nim kryzysu gospodarczego. W ostatniej części podsumowano wyniki analizy.

\section{Neoinstytucjonalizm według Douglassa Northa}

W 1993 r. Nagroda Banku Szwecji im. Alfreda Nobla została przyznana dwóm ekonomistom ze Stanów Zjednoczonych - Robertowi Foglowi oraz Douglassowi Northowi. W uzasadnieniu przyznania wyróżnienia Królewska Szwedzka Akademia Nauk wskazała, że obaj badacze ,poszukując odpowiedzi na pytania,

\footnotetext{
* Michał Laskowski - magister, Uniwersytet Łódzki, Wydział Ekonomiczno-Socjologiczny, Katedra Międzynarodowych Stosunków Gospodarczych.
} 
dlaczego jedne kraje są biedne, a inne bogate, zastosowali najlepsze metody analizy ekonomicznej oraz materiał historyczny. Połączyli teorię ekonomii, metody ilościowe, testowanie hipotez, kontrfaktyczne alternatywy oraz tradycyjną metodologię historii gospodarczej dla zbadania oraz zrozumienia głębokich pytań i wyjaśnienia głębokich zmian" (Nobelprize.org 1993a).

Zarówno R. Fogel, jak i D. North są przedstawicielami jednego z nowszych nurtów teorii ekonomii, określanego mianem neoinstytucjonalizmu. Mniej więcej od połowy lat 80 . XX w. do czasu wybuchu kryzysu finansowego w $2008 \mathrm{r}$. i wywołanego nim kryzysu gospodarczego powszechnie przyjmowano, że udział w głównym nurcie ekonomii jest uzależniony od wykorzystywanych przez ekonomistów narzędzi badawczych. W związku z tym do ortodoksyjnego nurtu myśli ekonomicznej zaliczano dorobek tych naukowców, którzy stosowali metody ekonometryczne na szeroką skalę. Polegają one na identyfikowaniu kluczowych elementów decydujących o kształcie procesów ekonomicznych, a następnie badaniu zależności między nimi przy użyciu zaawansowanych narzędzi matematyki (Landerth, Colander 2005, s. 564-565). Opisana sytuacja może się wydawać nieco paradoksalna, kiedy weźmie się pod uwagę fakt, że podstawy ekonometrii zostały opracowane na potrzeby kierowania gospodarką i planowania w okresie II wojny światowej oraz tuż po niej, a w latach 80. i 90 . XX w. metody ilościowe stały się podstawowym narzędziem opisu i wyjaśniania rzeczywistości ekonomistów nurtu neoliberalnego, sprzeciwiającego się, przynajmniej deklaratywnie, wpływowi państwa na gospodarkę (Godłów-Legiędź 2010, s. 23-25). Konsekwencje kryzysu gospodarczego, z którym światowa gospodarka boryka się nieprzerwanie od 2009 r., wymusiły rewizję opisanego podejścia. Stosowane dotychczas metody analizy ekonomicznej okazały się nieskuteczne nie tylko w przypadku przewidywania turbulencji na rynkach finansowych, ale również w zakresie prognozowania skutków stosowania antykryzysowych narzędzi polityki gospodarczej (Blanchard, Leigh 2013; „The Guardian” 2013). Przyczyny zawodności metod ilościowych dostrzeżono w ich statycznym charakterze. Modele ekonometryczne, z powodu wysokiego poziomu zaawansowania oraz sformalizowania, wymagaja apriorycznego określenia zmiennych opisywanych oraz opisujących.

Skomplikowanie gospodarki, mnogość funkcjonujących w jej ramach podmiotów oraz ich wzajemnych relacji zmuszają ekonomistów posługujących się ekonometrią do arbitralnego określania fundamentalnych zależności. Oznacza to, że badacz ze skomplikowanej wiązki relacji stojącej za obserwowanym w danej chwili mechanizmem gospodarczym wydziela najistotniejsze, jego zdaniem, związki, aby następnie zbadać ich konstrukcję oraz funkcjonowanie w modelu, którego warunki brzegowe określa na podstawie swojej wiedzy, przyjętego wcześniej konceptu teoretycznego oraz intuicji. Problem polega na tym, że wybierając zmienne, które mają zostać włączone do modelu, łatwo pominąć często trudno mierzalne liczbowo czynniki, zasadniczo determinujące przebieg procesów ekonomicznych (Landerth, Colander 2005, s. 566). Historyczne, instytucjonalne 
oraz kulturowe uwarunkowania działania oraz zawodności rynku trudno umieścić w sformalizowanym modelu ekonometrycznym o ograniczonym, z przyczyn metodologicznych, zakresie i limitowanej międzyokresowej dynamice (Frydman, Goldberg 2009, s. 45-52).

Transformacja ustrojowa gospodarek od realnego socjalizmu do wolnego rynku w latach 90. XX w. oraz trudne do przezwyciężenia skutki globalnego kryzysu gospodarczego mającego swój początek w kryzysie finansowym z $2008 \mathrm{r}$. pokazały, że działanie rynku nie zależy wyłącznie od mechanizmu ustalania cen, ale również od jego osnowy instytucjonalnej przekładającej się na sposób, w jaki ludzie postrzegają logikę jego działania oraz reagują na jego dysfunkcje (Godłów-Legiędź 2010, s. 38-40). Robert Fogel oraz Douglass North w trakcie swoich wieloletnich badań doszli do wniosku, że narzędzia ekonomii neoklasycznej, z powodu wspomnianych ograniczeń, nie są wystarczające do wyjaśnienia przemian gospodarczych zachodzących na przestrzeni wielu stuleci (North 2014, s. 9).

Punktem wyjścia rozważań niniejszej pracy będą osiągnięcia D. Northa, którego dorobek różni się od spuścizny R. Fogla tym, że D. North bardziej koncentruje się na instytucjach rynku niż historycznych determinantach działania jego mechanizmów (Nobelprize.org 1993b). Uznano, że odwołanie się do teorii neoinstytucjonalizmu Northa jest właściwsze, skoro historia najstarszych banków centralnych funkcjonujących na świecie pozwala wysnuć wniosek, że działalność władz monetarnych jest silniej determinowana przez siatkę instytucji rynku niż historyczne dziedzictwo (Bordo 2007, s. 1).

Droga naukowa D. Northa jest interesująca, ponieważ wiedzie od marksistowskich i pacyficznych poglądów - które uczony wyznawał, rozpoczynając studia na University of California w Berkeley - przez silne wsparcie dla wolnego rynku i własności prywatnej dostrzegalne w jego wczesnych pracach naukowych, po skoncentrowanie się na nowych dla ekonomii XX w. pojęciach kosztów transakcyjnych i prawa własności u szczytu kariery (North 2014, s. 11). Ewolucja poglądów Northa świadczy o tym, że opanował on aparat badawczy niezbędny do zrozumienia przemian gospodarczych. Równocześnie dostrzegł prawidłowości determinujące wzrost i rozwój gospodarczy w szerszym zakresie niż naukowcy unikający poddawania swoich poglądów daleko posuniętej krytyce. Przełom w postrzeganiu zjawisk gospodarczych u Northa dokonał się pod wpływem wniosków wysnutych przez ekonomistę na podstawie sięgających średniowiecza danych o funkcjonowaniu gospodarki europejskiej. Pozwoliły one badaczowi na dostrzeżenie związków między wzrostem i rozwojem gospodarczym a ewolucją systemów instytucjonalnych krajów Europy Zachodniej. North zaobserwował, że różne społeczeństwa funkcjonują w oparciu o odmienne systemy przekonań i wartości. Odnotował również, że w poszczególnych krajach inaczej zostało skonstruowane państwo stojące na straży systemów wartości społeczeństw i gwarantujące przestrzeganie reguł społecznych. W efekcie amerykański badacz zaczął zastanawiać się nad tym, co sprawiło, że w niektórych krajach miał miejsce intensywny 
rozwój gospodarczy, któremu towarzyszyła ewolucja systemu instytucjonalnego, podczas gdy inne państwa, utrzymując niezmieniony system wartości, borykały się z rozwojowym dryfem lub wręcz recesją i regresem (North 2014, s. 13). W tym miejscu należy zauważyć, że mówiąc o charakteryzujących społeczeństwa systemach wartości, nie można przyjmować założenia, że wszyscy członkowie społeczeństwa wyznają zgodnie te same wartości. Chodzi raczej o stwierdzenie, że w danym okresie instytucje organizujące społeczeństwo są przejawem dominującego systemu wartości, jednak istnieją systemy alternatywne i opozycyjne, które $\mathrm{w}$ danej chwili nie mają poparcia wystarczającego do zmiany instytucji. Innymi słowy, system wartości społeczeństwa nie jest wewnętrznie spójny, tylko jest efektem ścierania się różnych wartości, np. przekonania o konieczności oddziaływania państwa na gospodarkę oraz poglądu, że niewidzialna ręka rynku może samoczynnie zapewniać ogólnorynkową równowagę.

Fundamentalnym dla neoinstytucjonalizmu oraz ortodoksyjnego nurtu teorii ekonomii wnioskiem Northa jest stwierdzenie, że nie jest możliwe skonstruowanie modelu ekonometrycznego, który byłby w stanie dostatecznie precyzyjnie określać determinanty wzrostu gospodarczego. Powodem takiego stanu rzeczy jest fakt, że ekonomia neoklasyczna (ekonomia głównego nurtu / nurtu ortodoksyjnego) opiera się na pojęciu równowagi ogólnej, które drastycznie ogranicza zdolności modeli opartych na tym założeniu do badania dynamicznych zmian. Równowaga ogólna miałaby polegać na równowadze wewnętrznej trzech fundamentalnych dla gospodarki rynków: rynku dóbr i usług, rynku kapitału oraz rynku pracy, a także na zewnętrznej równowadze między nimi (Blanchard 2011, s. 209-2014; Krugman, Wells 2011, s. 321). Ponadto ekonomia neoliberalna zakłada naturalną zdolność rynku do powracania do punktu równowagi, jeśli został on z niej wcześniej wytrącony (Landerth, Colander 2005, s. 559-563). Wspomniany konstrukt, zdaniem Northa, charakteryzuje się bardzo niską dynamiką, w przeciwieństwie do niezwykle dynamicznej gospodarki, dlatego nie jest on odpowiedni do możliwie najpełniejszego opisu zjawisk gospodarczych.

Stwierdzenie to jest kluczowe w odniesieniu do polityki pieniężnej, która współcześnie opiera się na zaawansowanych modelach matematycznych, służących nie tylko analizie bieżących i przeszłych zjawisk gospodarczych, ale stanowiących również narzędzia formułowania prognoz w zakresie kształtowania się wielkości makroekonomicznych w przyszłości. Na ich podstawie podejmowane są decyzje dotyczące wykorzystania instrumentów polityki pieniężnej, które, oddziałując na podaż pieniądza i stopy procentowe, przekładają się na tempo wzrostu cen oraz tempo wzrostu gospodarczego w przyszłości (Sławiński 2011, s. 67-69; Bernanke, Woodford 1997, s. 1-6). Jeżeli decyzje banków centralnych $\mathrm{w}$ dużej mierze podejmowane są na podstawie przesłanek płynących z modeli, które prawdopodobnie niedostatecznie odzwierciedlają mechanizmy funkcjonowania rynku, to analiza polityki monetarnej przez pryzmat instytucji, na jakich się opiera, może dostarczyć interesujących oraz użytecznych wniosków. 
Doulgass North w swoich badaniach posługuje się najczęściej dwuelementowym wzorcem analitycznym. Pierwszym jego członem jest schemat badawczy, skonstruowany na potrzeby analizy siatki instytucjonalnej determinującej działanie rynku oraz społeczeństwa. Drugą z części składowych wzorca jest użycie skonstruowanego schematu do analizy konkretnych okresów i/lub krajów (North 2014, s. 12).

Celem badawczym niniejszej pracy jest weryfikacja hipotezy, że na skutek przemian gospodarczych wywołanych kryzysem finansowym z 2008 r. oraz spowodowanym nim kryzysem gospodarczym nastąpiła zmiana wartości polityki pieniężnej Europejskiego Banku Centralnego.

Realizacja założenia badawczego została podzielona na dwa etapy. Pierwszy z nich polega na zidentyfikowaniu zespołu instytucji, za pomocą których EBC realizował politykę monetarną przed $2008 \mathrm{r}$. Drugi zaś polega na porównaniu obecnego zespołu instytucji polityki pieniężnej UGiW z siatką instytucjonalną polityki monetarnej strefy euro sprzed $2008 \mathrm{r}$.

Aby zachować spójność wywodu, należy wprowadzić w tym miejscu pojęcia „zmiana gospodarcza” oraz ,instytucja”. Otóż mechanizm zmiany gospodarczej obejmuje wiele przemian, w szczególności (North 2014, s. 21):

1) zmiany w liczebności oraz cechach ludzi;

2) zmiany w zasobach ludzkiej wiedzy, sposobach jej rozpowszechniania, zwłaszcza w zakresie ograniczania negatywnych skutków działania sił przyrody;

3) zmiany instytucjonalne, określające intencjonalny system zakazów i nakazów dla członków społeczeństwa.

Dalsze rozważania będą się odnosić głównie do trzeciego typu przemian, do zmian instytucjonalnych. Wynika to ze szczególnej roli instytucji w kształtowaniu rynków, która jest pochodną następującego ciągu przyczynowo-skutkowego; ludzie w ciągu wielu tysięcy lat ewolucji zyskali świadomość, dzięki której zrodziło się w nich dążenie do podporządkowywania sobie środowiska naturalnego. Szybko dostrzegli, że największe sukcesy w tym zakresie są zdolni osiągać dzięki współpracy. Było to przyczyną wykształcenia się znanych dziś zinstytucjonalizowanych struktur rynku. Współpraca między ludźmi wymaga zwykle zrzeczenia się przez każdego z kooperujących pewnej dozy autonomii. Z tego powodu system gospodarczy nie jest w stanie opierać się jedynie na dobrej woli egoistycznych istot, jakimi są ludzie. Jego trwałość jest ugruntowywana wieloma ograniczeniami, które biorą na siebie członkowie społeczeństwa. North dostrzegł, że struktura tych ograniczeń może prowadzić do wzrostu i rozwoju gospodarczego lub stagnacji i regresu (North 2014, s. 29). Opisany mechanizm znajduje zastosowanie w opisie każdego rynku, również rynku politycznego, będąc kluczem do wyjaśnienia złożonych przemian gospodarczych.

Innym czynnikiem, obok możliwości odniesienia korzyści z wymiany, popychającym ludzi do przyjmowania na siebie różnego rodzaju ograniczeń jest ewolucyjnie i psychologicznie uwarunkowana awersja do ryzyka (Kahneman 2012, 
s. 411-426). Ludzie są skłonni ograniczać swoją autonomię, aby w ramach społeczeństwa oraz struktur rynkowych minimalizować ryzyko towarzyszące każdej decyzji. Niejednokrotnie, pomimo zastosowania limitów instytucjonalnych i aksjologicznych, zmniejszenie niepewności nie jest możliwe. W takich skrajnych przypadkach siatka instytucjonalna tworzona przez społeczeństwo umożliwia skonkretyzowanie nieprzewidywalności do mierzalnego, choćby intuicyjnie, ryzyka (North 2014, s. 32).

W odniesieniu do podmiotów rynku konieczne jest nieustanne poszukiwanie możliwości poprawy swojej sytuacji w ramach ciągle zmieniającej się matrycy instytucjonalnej, ustanawiającej system ograniczeń działalności. Należy w tym miejscu zaznaczyć, że pojęcie działalności nie musi odnosić się jedynie do działalności gospodarczej. Jak wspomniano wcześniej, system instytucji determinuje całe życie społeczne. W konsekwencji zamiary jednostek mających decydujący wpływ na układ ograniczeń nie zawsze muszą być tożsame z interesem gospodarczym. Może się zatem zdarzyć tak, że definicje granic wolności społecznej zostaną ustanowione tak, że nie będą one sprzyjać wzrostowi oraz rozwojowi gospodarczemu. Ludzie, funkcjonujący w świecie nieustannie borykającym się z problemem asymetrii informacji, mogą podejmować działania, których konsekwencje będą sprzeczne $\mathrm{z}$ ich pierwotnymi intencjami. Historia gospodarcza świata jest wypełniona skutkami takich działań. Jak nieco nostalgicznie zauważa North: historia gospodarcza [świata - przyp. ML] jest przygnębiająca opowieścia o błędnych kalkulacjach prowadzacych do klęsk głodu, wojen, śmierci, stagnacji gospodarczej i upadku, a nawet zniknięcia catych cywilizacji (North 2014, s. 34).

Za wspomnianymi w cytacie tragediami, tak samo jak za sukcesami ludzkości, do których można zaliczyć spektakularny wzrost gospodarczy w kilku minionych stuleciach (Kołodko 2011, s. 45-46), stoi nieustannie ewoluująca matryca instytucjonalna. Jest ona kombinacją reguł formalnych oraz nieformalnych, wyznaczających ograniczenia wraz ze środkami ich egzekwowania.

Reguły formalne są przez Northa określane mianem instytucji formalnych. Zalicza on do nich przepisy prawa regulujące stosunki polityczne oraz ekonomiczne, poczynając od ustaw zasadniczych, na wewnętrznych regulaminach i kodeksach dobrych praktyk przedsiębiorstw i stowarzyszeń kończąc. Formalnymi instytucjami mającymi największe znaczenie dla funkcjonowania rynku są prawo własności oraz prawo kontraktowe (Landerth, Colander 2005, s. 566). System instytucji formalnych tworzy matrycę instytucjonalną wraz z instytucjami nieformalnymi. Na kształt tych ostatnich mają wpływ dziedzictwo kulturowe oraz historyczne, na które składają się: normy moralne, zwyczaje, obyczaje, wierzenia religijne oraz mentalność jednostek. Instytucje nieformalne są przekazywane kolejnym pokoleniom za pomocą edukacji i naśladownictwa.

Tym, co motywuje jednostki do działania w ramach obecnie obowiązującej matrycy instytucjonalnej, jest system kar. Jeżeli jest on prawidłowo skonstruowany, istotnie zwiększa koszty działań skierowanych przeciwko obowiązującym 
instytucjom formalnym oraz nieformalnym. W takiej sytuacji podmioty rynkowe, czy szerzej - członkowie społeczeństwa, zdecydują się na działanie wbrew formalnym i nieformalnym instytucjom wówczas, gdy korzyści z takiego postępowania będą przewyższały koszty wystąpienia przeciw powszechnie obowiązującym wartościom i zasadom. Racjonalność jednostki jest zatem silnie subiektywna, dlatego trudno ją analizować za pomocą modeli ekonomii neoliberalnej (Smith 2013, s. 34-35). Racjonalność jednostki musi zatem być osadzana w społecznym oraz historycznym kontekście (Landerth, Colander 2005, s. 567).

W kolejnej części pracy zidentyfikowana zostanie matryca instytucjonalna stojąca za wartościami i zasadami polityki gospodarczej w UGiW.

\section{Siatka instytucjonalna polityki pieniężnej w UGiW}

Polityka pieniężna jako jedno z głównych narzędzi polityki makroekonomicznej pozostaje pod wpływem instytucji formalnych oraz nieformalnych. Jako aktywna forma oddziaływania państwa na gospodarkę polityka monetarna nie tylko funkcjonuje w ramach istniejącej struktury instytucji, ale jest również zdolna do jej modelowania. Poniżej zostaną przedstawione formalne oraz nieformalne instytucje i wartości polityki pieniężnej w Unii Gospodarczej i Walutowej (UGiW).

\section{Formalne instytucje polityki monetarnej w UGiW}

Formalne instytucje ustanawiające ramy istnienia i działania banku centralnego zapisane są w aktach prawnych. Wspomniane instytucje można podzielić, na podstawie charakteru ich wpływu na władze monetarne, na dwie grupy: regulacje ustanawiające władze monetarne oraz akty prawne konstytuujące narzędzia polityki pieniężnej pozostające $\mathrm{w}$ dyspozycji banku centralnego. Przytoczony podział znajduje odzwierciedlenie w hierarchii aktów prawnych, w których zostały zawarte postanowienia dotyczące istnienia władz monetarnych oraz ich działalności. Otóż Europejski Bank Centralny (EBC) działa na podstawie o art. 3 oraz art. 13 Traktatu o Unii Europejskiej (TUE). Główne postanowienia odnoszące się do EBC zostały zawarte w art. 3 ust. 1 lit. c, art. 119, art. 123, art. 127-134, art. 138-144, art. 219 oraz w art. 282-284 Traktatu o Funkcjonowaniu Unii Europejskiej (TFUE). Narzędzia polityki pieniężnej wraz ze szczegółowymi zasadami ich wykorzystania zapisano w statusach EBC oraz Europejskiego Systemu Banków Centralnych (ESBC).

W przypadku niniejszego opracowania kluczowe są te wartości, które determinują działanie EBC. Uznano tutaj ich nadrzędną rolę, tzn. przyjęto założenie, zgodnie z którym narzędzia, jakimi posługuje się bank centralny strefy euro, zostały zaprojektowane tak, aby umożliwiać mu wykonywanie stawianych przed nim zadań. Nie może zatem dojść do sytuacji, w której narzędzia polityki monetarnej strefy euro będą niewystarczające do osiagania celów polityki pieniężnej lub umożliwiają 
władzom monetarnym świadome działanie wbrew jej zobowiązaniom. W tabeli 1 zawarto przegląd wymienionych artykułów dotyczących EBC oraz ESBC.

Tabela 1. Przegląd artykułów prawa traktatowego UE zawierających regulacje dotyczące EBC i ESBC

\begin{tabular}{|c|c|c|c|}
\hline Traktat & $\begin{array}{l}\text { Przepis prawa } \\
\text { traktatowego }\end{array}$ & Zakres regulacji & $\begin{array}{l}\text { Instytucja lub wartość istotna } \\
\text { dla polityki pieniężnej EBC }\end{array}$ \\
\hline \multirow{2}{*}{ 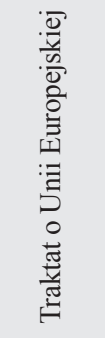 } & Art. 3., ust. 3 TUE & $\begin{array}{l}\text { Ustanowienie rynku wewnętrzne- } \\
\text { go wspierającego zrównoważony } \\
\text { wzrost gospodarczy, stabilność cen, } \\
\text { wysoką konkurencyjność, dążenie } \\
\text { do pełnego zatrudnienia, postęp } \\
\text { społeczny oraz ochronę środowiska }\end{array}$ & $\begin{array}{l}\text { Stabilność cen, pełne zatrudnie- } \\
\text { nie, konkurencyjność, postęp } \\
\text { społeczny }\end{array}$ \\
\hline & Art. 13 TUE & $\begin{array}{l}\text { Katalog instytucji UE; zaliczenie } \\
\text { w ich poczet EBC (bez ESBC), } \\
\text { odesłanie do szczegółowych } \\
\text { ustaleń w TFUE }\end{array}$ & $\begin{array}{l}\text { Przyznanie EBC statusu instytu- } \\
\text { cji UE; nadanie EBC nadrzędnej } \\
\text { pozycji w systemie polityki } \\
\text { monetarnej UGiW }\end{array}$ \\
\hline \multirow{10}{*}{ 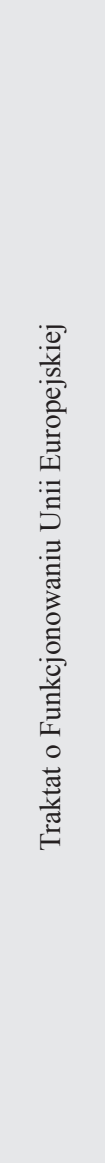 } & Art. 127 TFUE & Cele i zadania EBC & $\begin{array}{l}\text { Stabilność cen; pełne zatrud- } \\
\text { nienie, stabilność systemu fi- } \\
\text { nansowego, stabilność wzrostu } \\
\text { gospodarczego }\end{array}$ \\
\hline & Art. 128 TFUE & Monopol emisyjny EBC & Regale mennicze \\
\hline & Art. 130 TFUE & Niezależność EBC & Niezależność EBC \\
\hline & Art. 131 TFUE & $\begin{array}{l}\text { Nakaz wprowadzenia zgodności } \\
\text { krajowych systemów polityki } \\
\text { monetarnej z ESBC }\end{array}$ & $\begin{array}{l}\text { Wiodąca rola EBC w prowadze- } \\
\text { niu polityki pieniężnej ESBC }\end{array}$ \\
\hline & Art. 132 TFUE & $\begin{array}{l}\text { Uprawnienie EBC do nakładania } \\
\text { kar za niestosowanie się do jego } \\
\text { rozporządzeń i decyzji }\end{array}$ & $\begin{array}{l}\text { Zdolność EBC do zwiększania } \\
\text { kosztu przekraczania przez } \\
\text { podmioty gospodarcze ustalonej } \\
\text { siatki instytucjonalnej }\end{array}$ \\
\hline & Art. 133 TFUE & $\begin{array}{l}\text { Uprawnienie Rady UE do tworze- } \\
\text { nia środków zapewniających funk- } \\
\text { cjonowanie euro jako wspólnego } \\
\text { pieniądza po konsultacji z EBC }\end{array}$ & $\begin{array}{l}\text { Ograniczenie zdolności EBC do } \\
\text { zmiany matrycy instytucjonalnej. }\end{array}$ \\
\hline & Art. 219 TFUE & $\begin{array}{l}\text { Uprawnienie EBC do prowadze- } \\
\text { nia interwencji walutowych }\end{array}$ & Stabilność kursu walutowego \\
\hline & Art. 282 TFUE & $\begin{array}{l}\text { Nadanie osobowości prawnej EBC; } \\
\text { ustanowienie EBC jako centralnej } \\
\text { instytucji Europejskiego Systemu } \\
\text { Banków Centralnych; powtórzenie } \\
\text { głównego celu EBC - stabilności } \\
\text { wartości wspólnej waluty }\end{array}$ & $\begin{array}{l}\text { Wiodąca rola EBC w prowadze- } \\
\text { niu polityki pieniężnej ESBC; } \\
\text { stabilność cen w UGiW }\end{array}$ \\
\hline & Art. 283 TFUE & $\begin{array}{l}\text { Niezależność personalna członków } \\
\text { zarządu EBC }\end{array}$ & Niezależność EBC \\
\hline & Art. 284 TFUE & $\begin{array}{l}\text { Relacje pomiędzy EBC a Komisją } \\
\text { Europejską, Parlamentem Europej- } \\
\text { skim oraz Radą Unii Europejskiej }\end{array}$ & $\begin{array}{l}\text { Ograniczenie władzy EBC, odpo- } \\
\text { wiedzialność EBC przed innymi } \\
\text { instytucjami Unii Europejskiej }\end{array}$ \\
\hline \multicolumn{2}{|c|}{ Status EBC oraz ESBC } & \multicolumn{2}{|c|}{ Powtórzenie oraz doprecyzowanie przepisów traktatowych } \\
\hline
\end{tabular}

Źródło: opracowanie własne. 
Przedstawiona struktura formalnych instytucji konstytuujących istnienie oraz funkcjonowanie EBC pozwala opisać instytucjonalną siatkę polityki monetarnej UGiW.

Polityka pieniężna strefy euro jest jednym z filarów funkcjonowania tego ugrupowania integracyjnego. Ma ona za zadanie współtworzyć warunki dla stabilnego wzrostu gospodarczego, zrównoważonego rozwoju społecznego, wysoko konkurencyjnego rynku wewnętrznego oraz konkurencyjności międzynarodowej gospodarki UGiW. Warunki te sprowadzają się do zapewniania stabilności dwóch parametrów gospodarki: cen wewnątrz strefy euro oraz kursu euro wobec innych walut na takim poziomie, który będzie gwarantował równowagę pomiędzy wspieraniem eksportu a rozwojem gospodarek państw członkowskich. Dodatkowo władze monetarne UGiW zostały zobowiązane do dbania o stabilność sektora finansowego (Financial Stability Review 2015, s. 62-65). Należy to zadanie uznać za komplementarne $\mathrm{w}$ stosunku do wymienionych $\mathrm{w}$ art. 3 TUE. Uzasadnione jest to sposobem, w jaki bank centralny został wpisany w ustrój gospodarki otwartej. Mianowicie jest on pożyczkodawcą ostatniej instancji oraz dysponentem i wykonawcą monopolu emisyjnego pieniądza. W związku z tym wszystkie podmioty gospodarcze oraz gospodarstwa domowe są uzależnione od jego decyzji w zakresie zgłaszanego popytu na pieniądz. Innymi słowy, odbiorcy polityki pieniężnej w UGiW są uzależnieni od podaży pieniądza generowanej przez EBC. Podaż ta $\mathrm{w}$ decydującej mierze dokonuje się za pośrednictwem rynku finansowego w wyniku operacji depozytowo-kredytowych (Sławiński 2011, s.121-129). Bank centralny, aby móc skutecznie realizować politykę pieniężną, potrzebuje zatem sprawnie oraz stabilnie funkcjonującego rynku finansowego.

Polityka monetarna jest realizowana przez EBC $w$ ramach dwupoziomowej struktury organizacyjnej, składającej się z EBC oraz ESBC. W związku z tym, że ESBC nie ma osobowości prawnej, działa za pośrednictwem EBC. Wprowadzenie ESBC do ustroju UE miało wymiary symboliczny oraz praktyczny. Przede wszystkim stanowiło gest włączenia w proces integracji monetarnej wszystkich państw członkowskich UE, niezależnie od tego, czy posługują się one wspólnym pieniądzem (EBC 2008, s. 12-14). Ponadto związanie procesu decyzyjnego EBC z ESBC osłabiło władzę banku centralnego strefy euro, czyniąc siatkę instytucjonalną polityki pieniężnej UGiW bardziej podatną na zmiany. Należy w tym miejscu zaznaczyć, że kolegialny ESBC otrzymał w prawie europejskim przeciwwagę w postaci Eurosystemu, który zrzesza narodowe banki centralne państw strefy euro. Skomplikowana sieć powiązań między EBC, Eurosystemem a ESBC, choć ma prowadzić do równoważenia uprawnień banku centralnego strefy euro, jednocześnie nie podważa jego roli jako centralnej instytucji polityki pieniężnej UGiW. Takie rozwiązanie podyktowane jest specyficzną konstrukcją strefy euro. Funkcjonowanie wspólnego pieniądza wymaga od posługujących się nim krajów daleko posuniętej koordynacji polityki makroekonomicznej (Bryson 1994, s. 541-557). Utworzenie ponadnarodowych instytucji polityki gospodarczej, 
a także przypisanie im wartości do realizacji, wymaga od państw członkowskich ugrupowania integracyjnego zrzeczenia się istotnej części swojej suwerenności. Kraje członkowskie strefy euro scedowały na EBC własne uprawnienia w zakresie prowadzenia polityki pieniężnej. Nie zdecydowano się jednak nigdy na utworzenie jednolitej polityki fiskalnej.

Cały ciężar zapewnienia wysokiego poziomu efektywności oraz stabilności makroekonomicznej UGiW spoczął zatem na polityce monetarnej. Znacznie łatwiej jest realizować cele tej dziedziny polityki gospodarczej, kiedy decyzje w jej zakresie podejmowane są przez jedną instytucję, która dodatkowo skupia odpowiednie narzędzia. Wiodąca rola $\mathrm{EBC}$ w systemie polityki monetarnej strefy euro jest dodatkowo wzmacniana przez wyłączne prawo tej instytucji do nakładania kar za niestosowanie się przez odbiorców polityki monetarnej do jej decyzji. Zdolność banku centralnego strefy euro do podejmowania skutecznych prawnie działań potwierdza jego zdolność do efektywnego wpływania na kształt siatki instytucjonalnej polityki pieniężnej UGiW. Wobec tego stwierdzenie, że polityka pieniężna jest predestynowana do stabilizowania gospodarki wspólnego obszaru walutowego w związku ze swoją znacznie mniejszą bezwładnością w porównaniu z polityka fiskalną, nie będzie zbyt daleko posunięte. Pod pojęciem „bezwładność" należy rozumieć opóźnienia w realizacji polityki monetarnej (Disyatat 2008, s. 8-14). Opóźnienia we wdrażaniu polityki pieniężnej można zdefiniować jako czas upływający od momentu wystąpienia w gospodarce przesłanki do zastosowania danego instrumentu do momentu jego faktycznego wykorzystania. Dodatkowo czasu wymaga przetransmitowanie decyzji władz monetarnych w postaci impulsu monetarnego (zmiana podaży pieniądza / zmiana poziomu stóp procentowych) do publiczności. EBC nie został wyposażony w uprawnienie, które mogłoby niwelować negatywny wpływ opóźnien. Mowa tutaj o wyłącznej możliwości projektowania i wdrażania narzędzi realizacji polityki monetarnej. Traktaty stanowią, że o narzędziach polityki monetarnej EBC decyduje Rada Unii Europejskiej, bank centralny strefy euro jest jedynie konsultantem w tym zakresie. Można w tej konstrukcji prawnej dostrzec chęć odnalezienia kompromisu między efektywnością polityki gospodarczej a koniecznością ograniczania władzy banku centralnego.

Opisana niespójność czasowa polityki pieniężnej niewątpliwie przysparza trudności bankowi centralnemu, niemniej jednak są one znacznie mniej dolegliwe od analogicznych opóźnień zachodzących w przypadku planowania oraz wdrażania polityki fiskalnej. Ta ostatnia, aby czynić za dość zasadzie państwa prawa oraz pewności obrotu gospodarczego, wymaga planowania zmian w zakresie podatków raz wydatków budżetu państwa z rocznym lub większym wyprzedzeniem (Owsiak 2005, s. 764-768). Biorąc pod uwagę stopień skomplikowania procesu tworzenia budżetu UE oraz jego wieloletnie perspektywy wykonania, opóźnienia $\mathrm{w}$ realizacji polityki fiskalnej należy uznać za istotnie dłuższe w porównaniu z opóźnieniami w pezypadku polityki monetarnej, które wynoszą w UGiW 
przeciętnie 4-5 kwartałów, licząc od momentu wysłania przez EBC impulsu monetarnego (Falagiarda, McQuade, Tirpák 2015, s. 14-15). Wykonywanie przez Europejski Bank Centralny ustanowionych prawem traktatowym zadań wymaga sprawnie i stabilnie funkcjonującego, w ramach bieżących uwarunkowań społeczno-gospodarczych, rynku finansowego. W związku z tym kolejną niebagatelną wartością i jednocześnie zobowiązaniem bankowości centralnej UGiW jest dbanie o rozwój i stabilność tego rynku.

Zaprezentowana instytucjonalna siatka polityki monetarnej UGiW pozwala na stwierdzenie, że działalność Europejskiego Banku Centralnego ma koncentrować się przede wszystkim na zapewnianiu stabilności wartości wspólnego pieniądza, a w dalszej kolejności na stymulowaniu wzrostu gospodarczego zapewniającego redukcję bezrobocia. Należy jednak zaznaczyć, że w ramach rynku pracy bank centralny ma możliwość oddziaływania jedynie na bezrobocie przymusowe, czyli prowokowane przez niewystarczający popyt na pracę (Acocella 2002, s. 155). Umieszczenie w orbicie zainteresowania władz monetarnych strefy euro inflacji oraz bezrobocia świadczy o tym, że oba zjawiska gospodarcze uznano za szkodliwe, jeśli chodzi o postrzeganie europejskiego społeczeństwa. Ponadto EBC został zobowiązany do dbania o zrównoważony rozwój rynku finansowego, co z kolei znajduje uzasadnienie w konieczności zapewnienia sprawnego funkcjonowania mechanizmu transmisji impulsów monetarnych do sfery realnej, czyli umożliwienia bankowi centralnemu efektywnego oddziaływania na poziom cen oraz bezrobocie.

\section{Nieformalne instytucje polityki pieniężnej w UGiW}

Nieformalne uwarunkowania polityki monetarnej Europejskiego Banku Centralnego nierozerwalnie wiążą się z formalnymi regułami jego istnienia oraz działania. W związku z tym, że stanowią one uzupełnienie sfer nieuregulowanych przepisami prawa, jest ich jednak znacznie mniej i są mniej skomplikowane.

W odniesieniu do polityki pieniężnej UGiW należy wskazać dwie fundamentalne wartości bankowości centralnej. Mianowicie niezależność EBC oraz przejrzystość jego działań. Oba zjawiska nieuniknienie przenikają się i wzajemnie warunkują. Otóż władze monetarne mogą być prawdziwie niezależne tylko wtedy, gdy większość aspektów ich funkcjonowania jest nieustannie oceniana przez odbiorców polityki pieniężnej. Ocena taka może się dokonywać pod warunkiem, że decyzje wpływające na podaż pieniądza i za pomocą złożonego mechanizmu transmisji polityki pieniężnej na wymianę zachodzącą między uczestnikami gospodarki charakteryzują się pełną jawnością i są oznajmiane opinii publicznej wraz z ich szczegółowym uzasadnieniem, jak również wyjaśnieniem relacji między nimi a zadeklarowanymi wcześniej celami oraz strategią polityki pieniężnej.

Pojęcie niezależności banku centralnego zostało wprowadzone do literatury przez Miltona Friedmana. Według niego niezależny jest ten bank centralny, który 
w realizacji polityki pieniężnej pozostaje poza wpływem rządu i, symetrycznie, nie wykazuje skłonności do wpływania na decyzje rządu, od których zależałyby warunki prowadzenia polityki pieniężnej (Taylor 2013, s. 1). Z operacyjnego punktu widzenia, jak wskazują S. Fischer oraz G. Debelle, niezależność banku centralnego jest wagą, jaką ma inflacja oraz stopa bezrobocia w funkcji celu władz monetarnych (Debelle, Fischer 1994, s. 206-212). Mianowicie im bardziej niezależny jest dany bank centralny, tym większą rolę w podejmowanych przez niego decyzjach będą odgrywać bieżące oraz przewidywane poziomy inflacji i bezrobocia. Jednocześnie decyzje władz monetarnych w mniejszym stopniu będą uwzględniały politykę rządu. Opisane teoretyczne koncepcje niezależności banku centralnego pozwalają dostrzec, że jest ona rozpatrywana w dwóch aspektach: politycznym oraz ekonomicznym (Przybylska-Kapuścińska 2008, s. 204-205). $\mathrm{W}$ sensie politycznym bank centralny jest niezależny wtedy, kiedy jest w stanie bez nacisku ze strony władzy wykonawczej określać swoje operacyjne cele (zawsze zgodne $\mathrm{z}$ celem strategicznym, czyli gwarantowaniem stabilności wartości pieniądza) wraz z narzędziami ich realizacji. Politycy władzy wykonawczej, którzy w demokratycznym ustroju dysponują inicjatywą ustawodawczą, mają możliwość kreowania ram instytucjonalnych działania banku centralnego. Aby zagwarantować tej instytucji polityczną niezależność muszą oni zrzec się wpływu na wybór osób zasiadających $\mathrm{w}$ jej zarządzie oraz zrezygnować $\mathrm{z}$ możliwości dyktowania im określonego sposobu postępowania, szczególnie w sytuacjach, w których decyzje podejmowane w ramach polityki pieniężnej mogłyby być niekorzystne dla cyklu wyborczego. W aspekcie ekonomicznym niezależność banku centralnego polega na zapewnieniu mu finansowania, które również pozostaje poza wpływem władzy wykonawczej.

Niezależność EBC jest gwarantowana przez przepisy traktatowe (art. 130 TFUE). Niemniej jednak są one jedynie ramami dla efektywnej suwerenności EBC. W sensie nieformalnym EBC oraz narodowe banki centralne Europejskiego Systemu Banków Centralnych, zarówno instytucje, jak i członkowie ich organów decyzyjnych, nie mogą zwracać się o udzielenie instrukcji ani przyjmować takowych nie tylko od innych instytucji UE, ale także od któregokolwiek z rządów państw członkowskich wspólnoty (EBC 2011, s. 9-15). Oznacza to, że zagwarantowana przez instytucje formalne niezależność banku centralnego strefy euro musi być nieustannie uzupełniana i rozszerzana przez nieformalne działania osób zasiadających w organach EBC w taki sposób, aby opierały się one wszelkim naciskom ze strony polityków, również takim, które mogą nie wynikać wprost z przepisu art. 130 TFUE. Można zatem stwierdzić, że niezależność EBC jest umocowana $\mathrm{w}$ siatce instytucjonalnej polityki pieniężnej strefy euro zarówno na poziomie instytucji formalnych, jak i nieformalnych. Aby umożliwić osobom sprawującym istotne funkcje w EBC zachowywanie niezależności, w przepisach traktatowych wprowadzono szereg zabezpieczeń. Po pierwsze, prezesi banków centralnych ESBC muszą być wybierani na kadencje nie krótsze niż 5 lat. Okres 
ten przekracza długość wyznaczanego kadencjami parlamentów cyklu politycznego, istotnie ograniczając możliwość zmian na tych stanowiskach podyktowanych zmianami opcji rządzącej. Członkowie zarządu EBC, w tym prezes, są wybierani na jeszcze dłuższe kadencje, aż 8-letnie, bez możliwości reelekcji. Jednocześnie odwołanie wymienionych osób jest możliwe tylko wówczas, gdy przestają one być zdolne do pełnienia funkcji, np. z powodu choroby, lub gdy popełnią przestępstwo. Ponadto rozstrzyganie sporów dotyczących działania EBC i ESBC jest domeną Trybunału Sprawiedliwości Unii Europejskiej. Taki zestaw formalnych instytucji wspierających niezależność banku centralnego UGiW daje możliwość ukształtowania się licznych nieformalnych zasad gwarantujących jego suwerenność, np. sporządzanie przez członków zarządu EBC sprawozdań z kontaktów z przedstawicielami rządów oraz Komisji Europejskiej.

W aspekcie ekonomicznym Europejski Bank Centralny jest niezależny pod dwoma istotnymi względami, chodzi o budżet i kapitał. Budżet EBC jest niezależny od budżetu UE i każdego z państw członkowskich. Z kolei udziałowcami EBC są banki centralne państw członkowskich strefy euro i ESBC (Vergote et al. 2010, s. 24-33). Taka konstrukcja prawna uniemożliwia politykom wpływanie na decyzje banku centralnego UGiW poprzez racjonowanie środków niezbędnych do jego sprawnego funkcjonowania.

Suwerenność banku centralnego strefy euro jest ugruntowywana przejrzystością jego funkcjonowania. Dzięki niej opinia publiczna jest w stanie ocenić, w jakiej mierze władze monetarne samodzielnie podejmują decyzje dotyczące polityki pieniężnej. Dodatkowo transparentność działalności władz monetarnych ułatwia podmiotom polityki pieniężnej ocenę wiarygodności banku centralnego, którą definiuje się zazwyczaj jako jego przywiązanie do jasno sformułowanych reguł i celów realizowanej polityki (Bordo, Silkos 2014, s. 4-7). Dzięki jawności działań władz monetarnych oraz rzetelnej polityce informacyjnej ujawniającej skutki podejmowanych przez nie decyzji dwie fundamentalne wartości polityki pieniężnej UGiW, jakimi są niezależność i wiarygodność Europejskiego Banku Centralnego, są akcentowane w świadomości społeczeństwa. Szczególny charakter wspomnianych dwóch parametrów polityki monetarnej wynika z tego, że wysoki poziom niezależności i wiarygodności EBC ogranicza koszty prowadzenia polityki pieniężnej. Jest to możliwe dzięki działaniu mechanizmu polegającego na podnoszeniu wrażliwości odbiorców polityki monetarnej na niemonetarne impulsy banku centralnego, np. perswazję werbalną. Innymi słowy, niezależny i wiarygodny bank centralny ma szansę wywierać wpływ na decyzje podmiotów rynkowych nie tylko za pomocą zmian wielkości monetarnych, takich jak podaż pieniądza czy poziom rynkowych stóp procentowych, ale również dzięki informowaniu odbiorców polityki pieniężnej o swoich zamiarach i potencjalnych reakcjach na zmiany sytuacji makroekonomicznej, np. deflacji lub inflacji. Publiczność, dostrzegając zgodność działań banku centralnego z jego wcześniejszymi deklaracjami, a także ich skuteczność, może samodzielnie dostosowywać swoje 
oczekiwania inflacyjne do przyjmowanego przez bank centralny celu. Oczywiście ogranicza to koszty dezinflacji i redukuje ryzyko inflacji wynikającej z oczekiwań podmiotów gospodarczych (Sławiński 2011, s. 142-148), gdyż pozwala władzom monetarnym osiągać przyjęte cele bez angażowania kosztowych konwencjonalnych narzędzi polityki monetarnej, takich jak operacje otwartego rynku, czy zmiany poziomu stopy rezerw obowiązkowych.

Przejrzystość wspólnej polityki pieniężnej Europejskiego Banku Centralnego oznacza jasne, otwarte i terminowe udostępnianie odbiorcom polityki monetarnej i szeroko pojmowanej opinii publicznej wszelkich istotnych informacji na temat jego celów i strategii, ocen podejmowanych decyzji, a także stojących za nimi procedur.

Opisane zależności między nieformalnymi instytucjami polityki pieniężnej UGiW, tj. niezależnością, wiarygodnością oraz przejrzystością działań EBC, pozwalają wyprowadzić kolejną, nieuregulowaną $\mathrm{w}$ pełni w prawie traktatowym, instytucję wspólnej polityki monetarnej, mianowicie zdyscyplinowanie Europejskiego Banku Centralnego oraz Europejskiego Systemu Banków Centralnych. Budowanie wiarygodności banku centralnego strefy euro w oparciu o niezależność i przejrzystość wymaga od decydentów polityki pieniężnej przyjęcia dyscypliny polegającej na konsekwencji w podejmowaniu decyzji i ujawnianiu ich publiczności. Zdyscyplinowanie władz monetarnych stabilizuje politykę pieniężną UGiW, chroniąc ją przed destabilizacją sytuacji monetarnej w obszarze wspólnej waluty, dzięki zmianom w celach i strategii polityki pieniężnej podejmowanych pod wpływem krótko- i średniookresowych czynników, takich jak sezonowe wahania poziomu bezrobocia lub wzrost cen transmitowany spoza UE (Schaal 1996, s. 309-319).

Konsekwencją zdyscyplinowania EBC w zakresie polityki pieniężnej jest przewidywalność jego działań. Bank centralny strefy euro regularnie ogłasza strategię polityki monetarnej, jaką ma zamiar stosować w średnim okresie. Opinia publiczna jest też regularnie informowana o ocenie zmian sytuacji makroekonomicznej we wspólnym obszarze walutowym, a także o działaniach, jakie w związku z nimi bank centralny planuje podjąć w średnim okresie. Przewidywalność polityki pieniężnej EBC ułatwia podmiotom gospodarczym dostosowywanie swoich przewidywań i działań do zmieniających się pod wpływem polityki pieniężnej warunków wymiany, dzięki czemu znacznie skraca się proces transmisji impulsów monetarnych do sfery realnej, co zwiększa efektywność polityki EBC w tym sensie, że decyzje banku centralnego stają się skuteczne w krótszym czasie, a koszty ich wejścia w życie w porównaniu z sytuacją, gdyby prowadzona była dyskrecjonalna polityka monetarna, są niższe (Wilhelmsen, Zaghini 2005, s. 21-24).

Podsumowując rozważania dotyczące nieformalnych instytucji polityki pieniężnej w UGiW, należy stwierdzić, że nieusankcjonowana prawnie część matrycy instytucjonalnej wspólnej polityki pieniężnej w strefie euro obejmuje: niezależność, wiarygodność, przejrzystość, zdyscyplinowanie oraz przewidywalność 
działań EBC. Nieformalne instytucje polityki monetarnej wspólnego obszaru walutowego pozostają w ścisłym związku z instytucjami formalnymi. Zależność ta polega na tym, że przepisy prawa oraz narzędzia ich egzekwowania, jakimi dysponuje EBC, wyznaczające granice jego działalności, ustanawiają ramy wypełniane wieloma niewynikającymi wprost z prawa UE działaniami, dzięki którym polityka monetarna UGiW z jednej strony podlega kontroli społeczeństwa, a z drugiej staje się istotnym parametrem podejmowanych przez nie działań.

\section{Siatka instytucjonalna polityki pieniężnej w UGiW po 2008 r.}

W literaturze przedmiotu oraz publicystyce dotyczącej funkcjonowania strefy euro panuje zgodność co do tego, że kryzys finansowy, który wybuchł w Stanach Zjednoczonych w 2008 r., a następnie, rozlewając się po światowej gospodarce, doprowadził do głębokiego kryzysu gospodarczego, istotnie zmienił cele polityki pieniężnej. Zmiany te nie ominęły również polityki monetarnej Europejskiego Banku Centralnego.

Fundamentalna zmiana miała miejsce w przypadku celu operacyjnego, stojącego przed bankiem centralnym strefy euro. Spowolnienie tempa wzrostu gospodarczego, z którym boryka się UGiW w wyniku kryzysu gospodarczego, sprawiło, że presja inflacyjna ustąpiła miejsca ryzyku deflacji (Polański 2015, s. 54-56). W związku z tym właściwą dyrektywą działania władz monetarnych strefy euro stało się wspieranie wzrostu gospodarczego, zgodnie z art. 3 TUE, gdyż działanie to $\mathrm{w}$ żadnej mierze nie zagrażało stabilności wartości wspólnego pieniądza. Antykryzysowa działalność EBC wymagała wyposażenia tej instytucji w niekonwencjonalne środki oddziaływania na podmioty rynkowe. Wynikało to $\mathrm{z}$ faktu, że dotychczasowe instrumentarium polityki monetarnej przestało być skuteczne, jeśli chodzi o pobudzanie wzrostu gospodarczego i redukcję bezrobocia. Polityka pieniężna Europejskiego Banku Centralnego, w związku z brakiem ponadnarodowej koordynacji polityk makroekonomicznych krajów członkowskich, opiera się na jednolitej stopie procentowej; w praktyce na zespole powiązanych ze sobą stóp procentowych, tworzących kanał dla rynkowej, referencyjnej stopy EONIA (ang. Euro Overnight Index Average).

Spowolnienie tempa wzrostu gospodarczego, któremu towarzyszyły wzrost bezrobocia oraz wzrost oprocentowania skarbowych papierów dłużnych większości państw UGiW, zmusiło EBC do zredukowania poziomów stóp procentowych do zerowych oraz ujemnych. W tej sytuacji uwaga banku centralnego zaczęła się skupiać na niekonwencjonalnych narzędziach polityki monetarnej, których celem stało się kierowanie podażą pieniądza - zamiast sterowania jego ceną - za pomocą mechanizmu stóp procentowych (Pattipeilohy et al. 2013, s. 16-27). EBC oddziaływał na podaż pieniądza przy użyciu zakrojonych na niespotykaną wcześniej skalę operacji otwartego rynku, przy czym konstrukcja tego instrumentu polityki 
pieniężnej uległa istotnym zmianom, polegającym na rozszerzeniu katalogu instrumentów finansowych będących jego przedmiotem, jak również wydłużeniu terminów ich zapadalności.

Wobec tego można stwierdzić, że kryzys finansowy i gospodarczy, z którym borykają się kraje strefy euro od 2008 r., doprowadził do dwóch istotnych zmian w działalności EBC. Po pierwsze, dominującą rolę w strukturze celów władz monetarnych strefy euro zyskał komplementarny cel polityki pieniężnej wspólnego obszaru walutowego, mianowicie wspieranie wzrostu gospodarczego i pełnego zatrudnienia. Stało się to możliwe dzięki zanikowi presji inflacyjnej. Po drugie, doszło do zmiany kompozycji instrumentarium, za pomocą którego EBC oddziałuje na podmioty rynkowe. Narzędzia skoncentrowane na sterowaniu stopami procentowymi straciły na znaczeniu. Polityka pieniężna jest obecnie realizowana przy użyciu narzędzi nakierowanych na sterowanie płynnością strefy euro.

\section{Podsumowanie}

Na podstawie przedstawionej w artykule analizy siatki instytucjonalnej określającej ramy działania Europejskiego Banku Centralnego można stwierdzić, że EBC funkcjonuje w oparciu o szereg formalnych i nieformalnych instytucji. Zależność między nimi polega na ustanawianiu przez przepisy prawa ram, które następnie wypełniane są wartościami wynikającymi z darzenia EBC, Eurosystemu oraz ESBC zaufaniem, jeśli chodzi o osiąganie celów Unii Europejskiej w ogóle i podporządkowanych im celów polityki monetarnej w szczególe. Formalne uregulowania działalności banku centralnego strefy euro konstytuują EBC jako centralną instytucję polityki gospodarczej wspólnego obszaru walutowego, wyposażając ją w narzędzia wystarczające do osiągania celów UE i UGiW, do których zaliczono: dbałość o stabilność wartości wspólnej waluty, wspieranie zrównoważonego wzrostu gospodarczego oraz działanie na rzecz rozwoju i stabilności systemu finansowego. Architektura zadań i narzędzi realizacji polityki monetarnej jest uzupełniana wieloma nieformalnymi instytucjami, z którymi wiążą się takie wartości jak: niezależność EBC, jego samodyscyplina, a także wiarygodność, przejrzystość i przewidywalność polityki pieniężnej. Instytucje nieformalne zwiększają efektywność wdrażania strategii jednolitej polityki pieniężnej. Kryzys finansowy z 2008 r. oraz wywołany nim kryzys gospodarczy spowodowały przewartościowanie celów polityki pieniężnej EBC, polegające na uznaniu komplementarnego wobec zwalczania inflacji zadania wspierania zrównoważonego wzrostu gospodarczego w UE za cel podstawowy wobec zaniku presji inflacyjnej. Ponadto coraz większe ryzyko deflacji doprowadziło do rozbudowy instrumentów prowadzenia wspólnej polityki pieniężnej oddziałujących na podaż pieniądza.

Nie ma jednak podstaw, aby stwierdzić, że zjawiska kryzysowe doprowadziły do istotnych zmian w siatce instytucjonalnej polityki pieniężnej UGiW. 
Wspomniane przewartościowanie celów EBC dokonało się w ramach istniejącego ich katalogu. Skupienie się władz monetarnych strefy euro na sterowaniu podażą pieniądza przy użyciu niekonwencjonalnych narzędzi w istocie rzeczy jest zwiększeniem możliwości wpływu banku centralnego na rynek finansowy, który również przed kryzysem pozostawał główną domeną jego oddziaływania. Biorąc pod uwagę większe zaangażowanie EBC w działania antykryzysowe, można wysnuć wniosek, że istniejąca siatka instytucjonalna została ugruntowana przez potwierdzenie wiodącej roli EBC w realizacji polityki gospodarczej, a także wzrost znaczenia nieformalnych instytucji i wartości jednolitej polityki pieniężnej, takich jak jej przejrzystość, przewidywalność i wynikająca z samodyscypliny władz monetarnych spójność.

\section{Bibliografia}

Acocella N. (2002), Zasady polityki gospodarczej. Wartości i metody analizy, PWN, Warszawa.

Bernanke B., Woodford M. (1997), Inflation Forecasts and Monetary Policy, The National Bureau of Economic Research, Working Paper No. 6157, New York.

Blanchard O. (2011), Makroekonomia, Wolters Kluwer Business, Warszawa.

Blanchard O., Leigh D. (2013), Growth Forecast Errors and Fiscal Multipliers, IMF Working Paper WP/13/1, International Monetary Fund, Washington DC.

Bordo M. (2007), A Brief History of Central Banks, Federal Reserve Bank of Cleveland, Cleveland, $\mathrm{OH}$.

Bordo M., Silkos P. (2014), Central Bank Credibility, Reputation and Inflation Targeting in Historical Perspective, Working Paper 20693, National Bureau of Economic Research, Cambridge, Massachusetts.

Bryson J. (1994), Fiscal policy coordination and flexibility under European Monetary Union: Implications for macroeconomic stabilization, „Journal of Policy Modeling", Vol. 16, Issue 6, Amsterdam.

Debelle G., Fischer S. (1994), How Independent Should a Central Bank Be?, Working Papers in Applied Economic Theory, 94-05, Federal Reserve Bank of San Francisco.

Disyatat P. (2008), Monetary policy implementation: Misconceptions and their consequences, BIS Working Papers, No. 269, Basel.

EBC (2008), The European Central Bank, The Eurosystem, The European System of Central Banks, European Central Bank, Frankfur am Main.

EBC (2011), The Monetary Policy of the European Central Bank, European Central Bank, Frankfurt am Main.

Falagiarda M., McQuade P., Tirpák M. (2015), Spillovers from the ECB's nonstandard monetary policies on non-euro area EU countries: evidence from an event-study analysis, Working Paper No. 1869, European Central Bank, Frankfurt am Main. 
Financial Stability Review (2015), European Central Bank, November, Frankfurt am Main.

Frydman R., Goldberg M. (2009), Ekonomia wiedzy niedoskonatej, Wydawnictwo Krytyki Politycznej, Warszawa. s. 45-52.

Godłów-Legiędź J. (2010), Współczesna ekonomia. Ku nowemu paradygmatowi?, C.H. Beck, Warszawa.

Kahneman D. (2012), Pułapki myślenia. O myśleniu szybkim i wolnym, Media Rodzina, Poznań.

Kołodko G. (2011), Wędrujacy świat, Prószyński i S-ka, Warszawa.

Krugman P., Wells R. (2011), Makroekonomia, PWN, Warszawa.

Landerth H., Colander D. (2005), Historia myśli ekonomicznej, PWN, Warszawa.

Nobelprize.org (1993a), The Sveriges Riksbank Prize in Economic Sciences in Memory of Alfred Nobel 1993, www.nobelprize.org/nobel_prizes/economicsciences/laureates/1993/ (data dostępu: 5.05.2016 r.).

Nobelprize.org (1993b), Douglass C. North - Facts, The Sveriges Riksbank Prize in Economic Sciences in Memory of Alfred Nobel 1993, www.nobelprize. org/nobel_prizes/economic-sciences/laureates/1993/north-facts.html (data dostępu: 3.05.2016 r.).

North D. (2014), Zrozumieć przemiany gospodarcze, Wolters Kluwer Business, Warszawa.

Owsiak S., Finanse publiczne, PWN, Warszawa.

Pattipeilohy C., van den End J.W., Tabbae M., Frosta J., de Haan J. (2013), Unconventional monetary policy of the ECB during the financial crisis: An assessment and new evidence, De Nederlandsche Bank NV, DNB Working Paper, No. 381, Amsterdam.

Polański Z. (2015), Otoczenie monetarne dla polityki zacieśniania fiskalnego [w:] Dylematy polityki makroekonomicznej w warunkach kryzysu zadlużeniowego w Unii Europejskiej, Oficyna Wydawnicza Szkoła Główna Handlowa w Warszawie, Warszawa.

Przybylska-Kapuścińska W. (2008), Wspótczesna polityka pieniężna, Difin, Warszawa.

Schaal P. (1996), Pieniadz i polityka pieniężna, PWE, Warszawa.

Sławiński A. (2011), Polityka pieniężna, CH Beck, Warszawa.

Smith V. (2013), Racjonalność w ekonomii, Wolters Kluwer Business, Warszawa. Taylor J. (2013), The Effectiveness of Central Bank Independence Versus Policy Rules [w:] Central Bank Independence: Reality or Myth?, American Economic Association Annual Meeting, San Diego, California.

TFUE, Traktat o Funkcjonowaniu Unii Europejskiej (wersja skonsolidowana), Dz. Urz. UE z dnia 26 października 2012 r. C326/01, ze zm.

The Guardian (2013), IMF admits: we failed to realise the damage austerity would do to Greece, www.theguardian.com/business/2013/jun/05/imf-underestimated-damage-austerity-would-do-to-greece (data dostępu: 03.05.2016 r.). 
TUE, Traktat o Unii Europejskiej (wersja skonsolidowana), Dz. Urz. UE z dnia 26 października 2012 r. C326/01, ze zm.

Vergote O., Stunder W., Efthymidas I., Merriman N. (2010), Main Drivers of The

European Central Bank Accounts and European Central Bank Financial Strenght over The First 11 Years, Occasional Paper No. 111, European Central Bank, Frankfurt am Main.

Wilhelmsen B., Zaghini A. (2005), Monetary Policy Predictability in the Euro Area. An international comparison, European Central Bank Working Paper No. 504, European Central Bank, Frankfurt am Main.

\section{Streszczenie}

Celem artykułu było zbadanie zmian, które zaszły w matrycy instytucjonalnej polityki pieniężnej Unii Gospodarczej i Walutowej po 2008 r. na skutek kryzysu finansowego i gospodarczego. Badanie zostało przeprowadzone na podstawie koncepcji instytucjonalizmu Douglasa Northa. W ramach dwuetapowej analizy opisano matrycę formalnych i nieformalnych instytucji polityki pieniężnej strefy euro, a następnie porównano jej strukturę ze strukturą przed rokiem 2008 i po nim. Wyniki analizy ujawniły zmiany w zakresie celów i narzędzi polityki pieniężnej; jednocześnie zostały zachowane struktury formalnych i nieformalnych instytucji polityki monetarnej UGiW sprzed kryzysu gospodarczego.

Slowa kluczowe: polityka pieniężna, matryca instytucjonalna, bankowość centralna

\section{Summary}

\section{Institutional Framework of Single Monetary Policy in The Economic and Monetary Union}

This paper aims to examine changes, which appeared within institutional framework of monetary policy in the Economic and Monetary Union after the crisis of 2008. Theoretical base for research was the new institutionalism under the methodological principles and criteria prepared by Douglass North. The analysis consist of two steps. The first describes institutional matrix of monetary policy in EMU. The second compares formal and informal institutions of monetary policy in the Eurozone before and after 2008. The analysis revealed, that changes have been made in monetary policy principles and tools. Nevertheless, institutional matrix was not changed.

Keywords: monetary policy, institutional matrix, central banking

JEL: B52, E58 